\title{
The relationship between defence policy, the defence budget, and force structure in contemporary Brazil ${ }^{1}$
}

\author{
Peterson Ferreira da Silva \\ Augusto W. M. Teixeira Júnior
}

\begin{abstract}
The roles and objectives of the Brazilian Armed Forces are strongly related to missions other than external security, despite having abundant natural resources to secure and regional interests that may be affected by great power competition in South America. Given this background, what are Brazil's main challenges regarding the relationship between defence policy, defence budget and force structure? To address this research problem, we explore an analytical approach that connects defence policy to budget execution in the context of civil-military relations in Brazil. The methodological framework of the paper is a qualitative approach, choosing a single case study as its research design. We adopted a broader historical perspective to raise observations to cope with the single-country study's classical limitations. Thus, the paper deals with two levels of analysis: domestic (Ministry of Defence) and international (geopolitical landscape). Based on official documents and budgetary data between 1999 and 2021, we trace the significant consequences of the Brazilian Armed Forces' continuous involvement in internal security issues, such as public security, border security, environmental crimes and migration crises. The paper reveals that Brazil's military spending, characterised by relatively high costs on personnel and low investments, has detrimental effects on defence acquisitions, training, readiness and operations. Our main argument is that a more active civilian direction and assertive defence policy are fundamental factors to balance the Brazilian Armed Forces personnel and investments expenditures.
\end{abstract}

Resumo: Os papéis e objetivos das Forças Armadas no Brasil estão fortemente relacionados a missões outras que não a segurança externa, apesar de ter recursos naturais abundantes para assegurar e ter interesses regionais que podem ser afetados pela competição entre grandes potências na América do Sul. Nesse contexto, quais são os principais desafios na relação entre política de defesa, orçamento de defesa e estrutura de força no Brasil? Para responder a este problema de pesquisa, exploramos uma abordagem analítica que conecta a política de defesa à execução orçamentária no quadro das relações civis-militares. A estrutura metodológica do artigo adota uma abordagem qualitativa, escolhendo um estudo de caso único como desenho de pesquisa. Para lidar com as limitações clássicas desse tipo de estudo, adotamos uma perspectiva histórica mais ampla para levantar observações. Assim, o texto trabalha com dois níveis de análise: nacional (Ministério da Defesa) e internacional (cenário geopolítico). Com base em documentos oficiais e dados orçamentários de 1999 a 2021, buscamos identificar as principais consequências do envolvimento contínuo das Forças Armadas em questões de segurança interna, tais como segurança pública, segurança de fronteiras, crimes ambientais e crises migratórias. O estudo mostra que o perfil do gasto militar brasileiro, caracterizado por gastos relativamente altos de pessoal e baixos investimentos, apresenta efeitos danosos para aquisições de defesa, treinamento, prontidão e operações. Nosso principal argumento é que uma direção civil mais ativa e uma política pública de defesa mais assertiva são fatores fundamentais para equilibrar os gastos de pessoal e de investimentos nas Forças Armadas.

\footnotetext{
${ }^{1}$ A draft version of this paper was presented at 'The Military in Politics in Brazil Conference 2021' - 27th and 28th May 2021, King's Brazil Institute - King's College London. We thank the anonymous reviewers for their comments and suggestions. The views expressed in this paper are those of the authors alone and do not necessarily reflect the official policy or position of any agency of the Brazilian government.
} 
During the last few decades, China has become South America's top trading partner and investor in several infrastructure projects, such as ports, roads and railways (Ellis, 2018; Nugent and Campell, 2021). In addition, it is possible to observe a deep Russian involvement in Venezuela, a country with one of the world's largest oil reserves. In recent years, Caracas has suffered from one of the biggest political and economic crises in its history. These regional instabilities have direct consequences to the Brazilian border area (e.g. Operation Welcome or Operação Acolhida, in Portuguese), among other geostrategic implications (Garganus, 2018; Herbst and Marczak, 2019; Lima, 2019; Teixeira Júnior, 2020).

Despite needing to secure plenty of natural resources and having regional interests that can be affected by great power competition in South America, the roles and objectives of the Brazilian Armed Forces are strongly related to missions other than external security. This situation is especially relevant given the tension between the contemporary implications from emerging technologies (e.g. artificial intelligence, cyberweapons, drones and hypersonic weapons) and the military's traditional roles in Brazilian society (e.g. border security, national development and Guarantee of Law-and-Order operations - GLO) (Silva, 2019a and 2019b). After all, the proliferation of disruptive technologies is only one of the contemporary challenges in defining a balance between current and future military capabilities within the parameters provided by defence policies and defence budget restraints (Taliaferro et al., 2019).

Since the creation in 1999 of the Ministry of Defence (MoD) (Brazil, 1999b), scholars have explored the challenges and advances in civil-military relations in Brazil (Fuccille, 2006; Soares, 2006; Oliveira, 2009; Bruneau, 2018). During the last decade, as internal security challenges grew in complexity, civilian political elites pushed the Brazilian Armed Forces to deal with issues not related to external security, such as border security, public security ${ }^{2}$, environmental crimes and migration crises (Lima and Medeiros Filho 2019; Lima, Silva and Rudzit, 2020a). However, few authors have explored this issue in the context of the relationship between defence policy, defence budget and force structure in Brazil (Brustolin, 2014; Silva, 2015; Cepik and Bertol, 2016).

To update this debate, we take an analytical approach that connects defence policy to budget execution. In this sense, the characteristics of civil-military relations are a relevant variable to solve this puzzle. The paper explores a qualitative methodological approach, using Brazil as a case study. To gather observations in a single country study, we adopted a broader historical perspective from 1999 to 2021. Based on official documents and budgetary data, the research deals with two levels of analysis to improve our inferences: the domestic level, with a focus on the role of the MoD, and the international level, exploring how the geopolitical landscape poses challenges to the structure of Brazilian forces.

To this end, we first point out some of the achievements and the challenges of Brazil's

\footnotetext{
${ }^{2}$ In this text, public security and public safety are synonyms. The terms mean, in general, protecting the wellbeing of people, communities, properties and public assets from crimes, disasters and other potential dangers, risks and threats. Some activities include, for example, law enforcement and policing, fire and disasters prevention and response, medical emergency services and corrections (Lima, Silva and Rudzit, 2020a, p. 17).
} 
national defence policies. Next, we highlight the context of civil-military relations in the country, exploring the link between civilian neglect of national security policymaking and the process of broadening the national defence concept in Brazilian official documents. In the third section, we analyse the recent geopolitical challenges faced by Brazil, especially concerning the great power competition in South America. Finally, we examine the link between the defence budget and force structure in contemporary Brazil.

\section{Achievements and challenges of Brazil's national defence policies}

In the context of the post-Cold War international literature on security and defence, it is possible to highlight two broad trends in national security and defence policymaking. First, the very concept of security has undergone changes, being broadened and deepened:

The traditional, state-centric understanding of security has gradually given way in recent years to what is widely referred to as the new security agenda. The new security agenda recognises the wide range of state and non-state actors that can act as security providers - or in some instances, as purveyors of insecurity. It also takes a broad view of security, understanding national security not only in military terms but also in terms of political, social, economic and environmental security (Buzan and Hansen, 2009).

Today national defence is understood as a sub-element of the broader security framework and its problems (Louth and Taylor, 2019, p. 27). The main idea is that defence cannot provide for security alone and can only be a part of the government's overall response to security problems (Dorman and Kaufman, 2014, p. 283). In this context, national security should not be understood solely in military terms 'but also in terms of political, social, economic and environmental security' (DCAF, 2012, p. 3). As Chile's 2017 White Paper and 2020 Defence Policy ${ }^{3}$ summarised well, national defence has become a more specific concept linked to the armed forces and military security:

Although defence and security are closely related, defence is a more specific concept than security, referring to the development and employment of military capabilities for tasks defined by the Constitution and laws. Defence alone does not produce the desired condition of security, but it is undoubtedly one of the essential factors in obtaining it (Chile, 2017, p. 102).

Therefore, the concept of national security became increasingly linked with human security. The key idea is that individuals, particularly vulnerable people, 'are entitled to freedom from fear and freedom from want, with an equal opportunity to enjoy all their rights and fully develop their human potential' (UN, 2016, p.6). In this sense, New Zealand's National Security Handbook, for

\footnotetext{
3 'Defence policy is complementary and implemented in coordination with foreign policy and other public policies related to the country's internal security and development' (Chile, 2020, p. 14).
} 
example, defines national security as 'the condition which permits the citizens of a state to go about their daily business confidently free from fear and able to make the most of opportunities to advance their way of life' (New Zealand, 2016, p. 7). More recently, the UK's Integrated Review of Security, Defence, Development and Foreign Policy presents security as 'the protection of our people, territory, CNI [critical national infrastructure], democratic institutions and way of life' (United Kingdom, 2021, p. 13).

Second, mainly due to this process of broadening and deepening the security concept, in recent decades, several countries have adopted national security policies or strategies (see Table 1). Those are official descriptions of 'how a state aims to provide for its own security and that of its population' (DCAF, 2015, p. 2). In general terms, a national security policy provides an understanding of national interests, objectives, values, principles, threats perceptions, governance mechanisms and decision-making processes and usually culminates in a long-term vision of State and human security in the future. It also guides the development of (i) specific policies for each of the instruments of national power (e.g. diplomatic, informational, military and economic) and (ii) multi-year and annual budgets. In short, national security policies/strategies guide defence policies/strategies, which in turn focus on force development (e.g. military capabilities and multiyear defence program budget), force employment (e.g. military operations) and logistics (e.g. defence industry governance).

\begin{tabular}{|c|c|c|}
\hline \multicolumn{2}{|c|}{ National Security Policies (2010-2021) - Examples } \\
\hline Country & Year & Title \\
\hline Austria & 2013 & Austrian Security Strategy \\
\hline Denmark & 2018 & Foreign and Security Policy Strategy 2019-2020 \\
\hline \multirow{2}{*}{ France } & 2013 & French White Paper on Defence and National Security \\
\cline { 2 - 4 } & 2017 & Defence and National Security Strategic Review 2017 \\
\cline { 2 - 4 } & 2021 & Strategic Update 2021 \\
\hline \multirow{2}{*}{ Germany } & 2016 & White Paper on Security Policy and the Future of the Bundeswehr \\
\hline Norway & 2017 & Setting the course for Norwegian foreign and security policy \\
\hline Poland & 2020 & National Security Strategy \\
\hline Russia & 2021 & Russian National Security Strategy \\
\hline Spain & 2013 & Estrategia de Seguridad Nacional 2013 \\
\cline { 2 - 4 } & 2017 & Estrategia de Seguridad Nacional 2021 \\
\cline { 2 - 4 } & 2021 & National Security Strategy \\
\hline Sweden & 2017 &
\end{tabular}


Silva, Peterson Ferreira; Teixeira Júnior, Augusto W. M. The relationship between defence policy, the defence Budget and force structure in contemporary Brazil.

\begin{tabular}{|c|c|c|}
\hline \multirow{3}{*}{$\begin{array}{c}\text { United } \\
\text { States }\end{array}$} & 2010 & National Security Strategy \\
\cline { 2 - 3 } & 2015 & National Security Strategy \\
\cline { 2 - 3 } & 2017 & National Security Strategy \\
\cline { 2 - 3 } & 2021 & Interim National Security Strategic Guidance \\
\hline \multirow{2}{*}{$\begin{array}{c}\text { United } \\
\text { Kingdom }\end{array}$} & 2010 & $\begin{array}{r}\text { A Strong Britain in an Age of Uncertainty: } \\
\text { The National Security Strategy }\end{array}$ \\
\cline { 2 - 3 } & 2015 & $\begin{array}{c}\text { The National Security Strategy } \\
\text { and Strategic Defence and Security Review }\end{array}$ \\
\cline { 2 - 3 } & 2021 & $\begin{array}{r}\text { Global Britain in a Comparative Age, the Integrated Review of } \\
\text { Security, Defence, Development and Foreign Policy }\end{array}$ \\
\hline
\end{tabular}

Table 1. National Security Policies (2010-2021) - Examples. Source: the authors.

In Brazil, there is no public policy on national security. Still, there are three documents focused on national defence: (i) the National Defence Policy (PND), (ii) the National Defence Strategy (END) and (iii) the National Defence White Paper (LBDN). These three documents are the results of the first National Defence Strategy (Brazil, 2008).

The 2008 National Defence Strategy is considered the first effective defence policy following the end of the Military Regime (1964-1985) and after the Defence Ministry's establishment in 1999 (Brazil, 1999b). Some Brazilian academics and military officers found the first National Defence Policy (PDN - 1996) to be excessively general for a defence policy, a criticism that was also made of the second one (PDN - 2005) (Oliveira, 2009).

The focus of the 2008 National Defence Strategy was on reorganising the Brazilian Armed Forces, restructuring the Brazilian defence industrial base and improving force structure. In addition, three strategic sectors were established and later placed under the responsibility of each of the military branches: the nuclear sector (Brazilian Navy), cybernetic sector (Brazilian Army) and space (Brazilian Air Force).

The 2008 Strategy also explicitly included a guideline to maintain compulsory military conscription, stating that 'the objective to be gradually pursued is to do military service, in fact, mandatory' (Brazil, 2008). It is important to emphasise that this guideline had the full support of the top civilian political leadership. For example, the Minister of Strategic Affairs at the time, Mangabeira Unger, publicly stated that there was 'a consensus among the leadership that compulsory military service should be maintained and deepened' as a 'republic leveller' (Zenker, 2008).

The Joint Chiefs of Staff (EMCFA - Estado-Maior Conjunto das Forças Armadas) and the position of the Chairman of the Joint Chiefs of Staff (CEMCFA - Chefe do Estado-Maior Conjunto das Forças Armadas) were created by Law 136/2010 (Brazil, 2010). However, it should be acknowledged that the CEMCFA is at the same level as the three military commanders (Navy, Army and Air Force). 
More importantly, this same law defined the Executive Branch's obligation to submit updates of the PND, END and LBDN to the National Congress every four years, starting in 2012. ${ }^{4}$

The main problem is that this quadrennial guideline has not evolved as expected between 2012 and 2020. The subsequent revisions of the Brazilian Defence Policy, Strategy and White Book (PND, END and LBDN) have been approved with delays. In addition, it also faced limitations in the consultation and drafting phase (e.g. independent non-government experts and parliamentary committees). The 2012 Brazilian Defence Policy, Strategy and White Book were approved one year later (Brazil, 2013a), and the 2016 versions were approved only in 2018 (Brazil, 2018a). More recently, the 2020 versions were sent to the Joint Congressional Committee on Intelligence (CCAI) in July 2020, instead of the existing defence committees - and, at the time of writing this paper in December 2021, the texts were still awaiting the final appraisal by the parliament.

\section{National security neglect and the enlargement of the national defence concept in Brazil ${ }^{5}$}

Before analysing the relationship between defence policy, defence budget and force structure in Brazil, it is important to mention three factors 'outside' the defence sector: (i) the marginalisation of the national security concept; (ii) the civilian political elite's lack of attention to intelligence matters after the 1988 Federal Constitution; and (iii) the increasing challenges in Brazilian' public security.

With the end of the military governments (1964-1985), security and defence matters and the very role of the State were open to debate, as were several fields of public policies. Broader issues such as the government's regulatory role, governance, governability, and promotion of development also awaited answers on the public agenda (Pereira, 1998). Since 1988, discussions of public policies directed to national security, defence, intelligence, and public security have followed different paths (Lima, Silva and Rudzit, 2020a).

'National security' practically disappeared from the 1988 Brazilian Constitution. There is only one mention of the term in the document, and it is related to economic activities ${ }^{6}$. However, Law No. 7.170 of 14 December 1983, which defines crimes against national security and political and social order, established during the military regime (Brazil, 1983), has only recently become the subject of public debate regarding its updating or revocation (Brazil, 2021).

Also, there is no policy guideline for the intelligence sector in the 1988 Constitution. The word intelligence effectively disappeared from the text ${ }^{7}$. Certainly, this omission results from the role played by the National Intelligence Service (SNI), created in 1964 during the military governments

\footnotetext{
${ }^{4}$ See Brazil (2010), Art. 9, § $3^{\circ}$.

${ }^{5}$ More details on this specific discussion in Lima, Silva and Rudzit (2020a).

6 ' [...] direct exploitation of economic activities by the State will only be allowed when necessary to national security imperatives or relevant collective interest' (Brazil, 1988, Art. 173).

${ }^{7}$ More details in Lima, Silva and Rudzit (2020a).
} 
(Antunes, 2002). After 1999, with the creation of the Brazilian Intelligence Agency (ABIN) and the Brazilian Intelligence System (SISBIN - Sistema Brasileiro de Inteligência), the intelligence sector gained a more precise direction. Even so, several challenges remain in this area. Cepik (2003, p. 207), for example, notes that the very definition of intelligence activity in the law that created ABIN and SISBIN was 'excessively vague'. The National Intelligence Policy (PNI), which was announced in the same Law 9.883/1999', was only established in 2016, 17 years later (Brazil (2016a). Similarly, the Joint Congressional Committee on Intelligence, announced in Law 9883/1999 , was only created in 2013-14 years later (Brazil, 2013b). In addition, ABIN has been subordinated to the president's Institutional Security Cabinet (GSI), and the latter has been led by retired four-star Army general officers since 1995. Finally, it is worth mentioning that the role of intelligence and public security against terrorism was only defined in 2016, 28 years after it was mentioned in the 1988 Federal Constitution (Brazil, 2016b; Lima, Silva and Rudzit, 2020a).

According to the 1988 Federal Constitution, public security became the responsibility of 27 federative units in Brazil: 26 states and the Federal District (Brazil, 1988, Art. 144). In each of 27 subnational states, there are civilian and military police forces subordinated to a state governor. At the federal level, we need to highlight the substantial role played in public security by the Federal Police (PF - Polícia Federal) and the Federal Highway Police (PRF - Polícia Rodoviária Federal), especially regarding drug trafficking and in the fight against corruption.

Coordination in public security is a great challenge in the context of a complex Brazilian judicial and criminal system. To address this, three initiatives can be highlighted: (i) the creation in 1997 of the National Secretariat of Public Security (SENASP - Secretaria Nacional de Segurança Pública); (ii) the establishment in 2007 of the National Program of Public Security with Citizenship (PRONASCI - Programa Nacional de Segurança Pública com Cidadania) (Brazil, 2007); and (iii) the creation in 2018 of the National Policy of Public Security and Social Defence (PNSPDS - Política Nacional de Segurança Pública e Defesa Social) and the Unified System of Public Security (SUSP - Sistema Único de Segurança Pública) (Brazil, 2018b). However, these initiatives were not enough to reduce the problems in Brazilian public security. These problems can be illustrated by, for example, the federal intervention (with the Armed Forces) in the public safety of the state of Rio de Janeiro in 2018 (Brazil, 2018c) and the police operation against drug trafficking in the Jacarezinho favela in 2021, considered the most lethal police operation in the last 16 years (Reuters, 2021).

The 1988 Brazilian Constitution therefore produced at least two interconnected problems. First, the lack of coordination, at the national level, for dealing with national security issues. Second, political elites and governments supported a process in which the Brazilian MoD and Armed Forces gradually took more institutional responsibilities. This background helps to demonstrate why broader issues at the level of national security, intelligence and public security ended up in the national defence agenda, with clear impacts on the role of the Brazilian Armed Forces (Silva, 2019). According to Lima, Silva and Rudzit (2020a), the roots of this broader defence sector lie in civilian

\footnotetext{
${ }^{8}$ See Brazil (1999a), Art. 5.

${ }^{9}$ See Brazil (1999a), Art. 6
} 
neglect regarding national security policymaking, as well as military resistance to broader defence reforms:

[...] since democratisation in 1985, civilian elites have neglected national security policymaking, and the military has since maintained several military prerogatives. Instead, as internal security challenges grew in complexity, civilian political elites pushed the military to deal with public safety, border security, and national security policymaking (Lima, Silva and Rudzit, 2020b).

That is one of the main reasons for the broadening of the national defence concept in Brazilian official documents and of the role of the Brazilian Armed Forces in the State and society. Lima and Medeiros Filho (2018, p. 13), for example, define this process as 'the enlargement of national defence concept'; that is, 'in the absence of mechanisms, institutions and supra-sectorial directions to address the country's strategic issues, such themes were inserted in the scope of the national defence sector'.

Also, it is crucial to note that successive Brazilian governments have insisted on elaborating and implementing uncoordinated policies for the areas of intelligence (National Intelligence Policy, PNI - 2016), national defence (PND, END and LBDN - 2012, 2016 and 2020) and public security (National Policy for Public Security and Social Defence, PNSPDS - 2018). Besides this fragmentation of public policies in the security sector, there are still two significant challenges for defence policy: the growing geopolitical challenges in Brazil's area of influence and the unpredictability of its defence budget.

\section{Main geopolitical challenges faced by Brazil ${ }^{10}$}

Among some current and possible emerging vulnerabilities, risks, and threats to Brazil, three topics can be identified: the great power competition in South America, the consequences of climate change on international politics and the military-technological innovation efforts in Brazil's Armed Forces.

The 21st-century's changing polarity comes with the redrawing of the international chessboard through the lens of geopolitics and geostrategy. In this scenario, Latin America is affected by great power rivalry, notably between the United States, China and Russia. In this context, Brazil may see its autonomy and its prospects of building a regional order threatened (Teixeira Júnior, 2018 and 2020).

The United States, China and Russia represent long-lasting lines in world geohistory and a great power struggle is emerging once again as the engine that drives the remaking of geopolitics in the present century. As a product of such trends, great power competition, containment strategies, counter-containment and hard balancing reappears in contemporary international politics (Kaplan, 2019).

Despite South America's historically marginal status in global affairs (Cairo, 2008), the region

\footnotetext{
${ }^{10}$ More details on this specific discussion in Teixeira Júnior (2018, 2019 and 2020).
} 
is now involved in international political processes as part of a broader geostrategic chessboard (Ellis, 2018). As shown in Figure 1, the dynamics of containment (the United States and allies) and counter-containment (China and Russia) have produced the effect of projecting great power competition beyond their immediate spheres of influence.

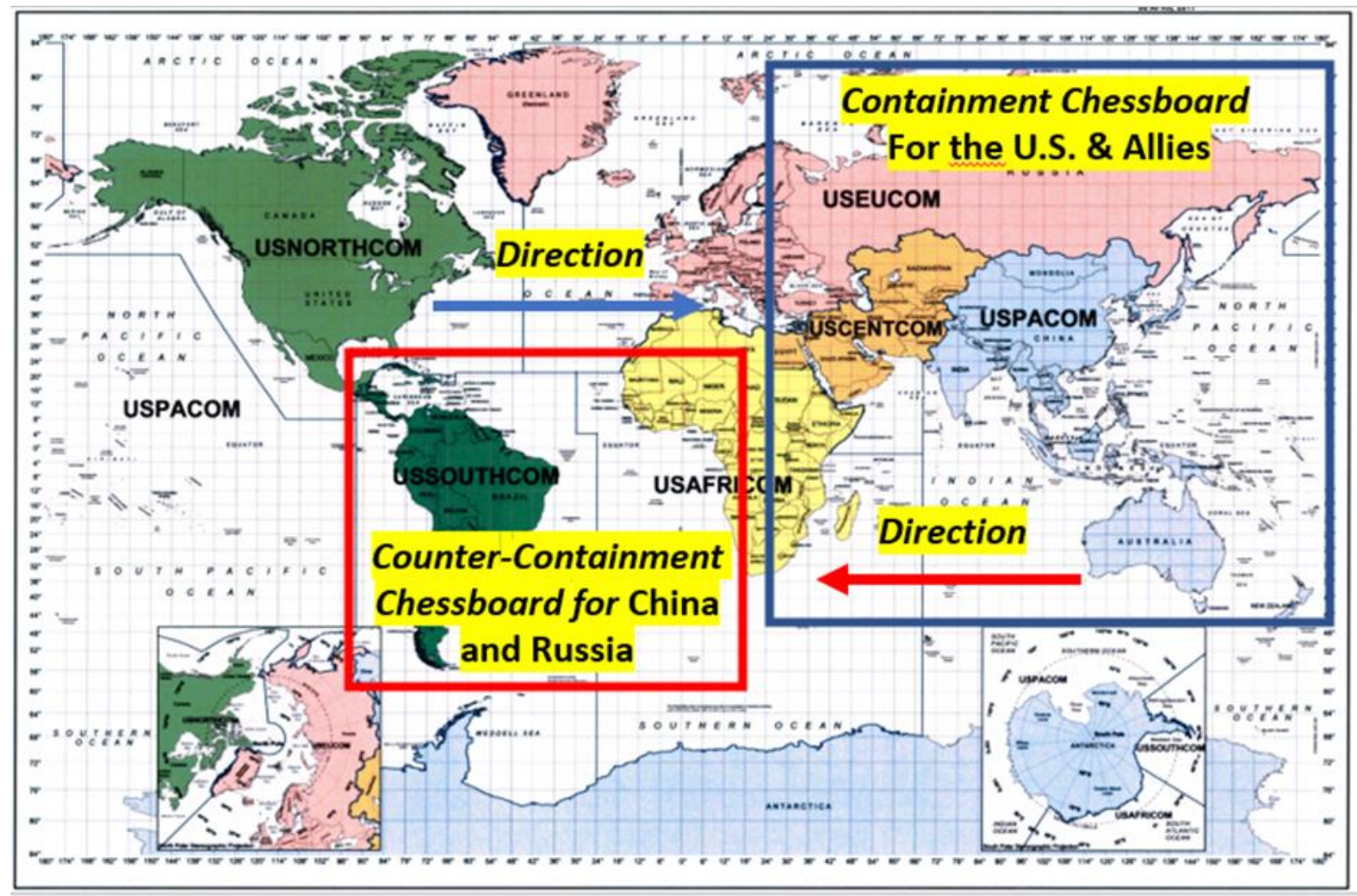

Figure 1. 'Containment and Counter-Containment Strategies and Spaces'. Source: the authors, based on 'The World with Commander's Areas of Responsibility', edition 9 NGA, Series 1107. Available at: https://archive.defense.gov/news/UCP 2011_Map4.pdf (Accessed: 15 August 2021).

Traditionally distant from the main tension hotspots, 'Brazil's strategic area of influence' (entorno estratégico brasileiro) is undergoing a process of reconfiguration in contemporary geopolitics. China and Russia, for example, see Latin America and Brazil as areas of influence and for diversionary manoeuvres to reduce the weight and pressure of the US in Eurasia (Ellis, 2018; Gurganus, 2018).

Another expressive challenge to Brazil and other South American countries is the consequences of climate change on international politics. Events caused by changing rainfall patterns, the melting of glaciers in the Andes, and more frequent and intense extreme weather events-such as droughts, floods and wildfires-can generate international pressures (e.g. Humanitarian Assistance and Disaster Response, HADR), tensions and conflicts (Alisson, 2021; Almazroui et al. 2021). In 2019, for example, the wildfires in Brazil's Amazon led to reactions among European leaders. On this occasion, French President Emmanuel Macron accused Brazilian 
President Jair Bolsonaro 'of lying about being committed to fighting climate change and protecting the Amazon Forest' (Pérez-Peña; Stevis-Gridneff, 2019).

Given Brazil's withdrawal from the international scene in recent years (Cervo and Lessa, 2014; Teixeira Júnior, 2020), as well as the presence of great powers in South America (Oner and Shehadeh, 2019; Mares, 2012), it is also necessary to mention military technological innovation efforts in Brazil's Armed Forces. Although it is unclear how and whether the MoD carries out effective direction and coordination of these processes, the fact is that each Brazilian military branch has distinct ideas of what military change means and how to manage it. Since the 2008 National Defence Strategy lead to the reorganisation of the Brazilian Armed Forces, each branch presented its idea of military change. The Navy prioritised modernisation, the Army opted for transformation and the Air Force adopted a reorganisation program (Teixeira Júnior, 2019).

As exemplified in projects such as KC-390 tactical transport aircraft, nuclear-powered and conventional submarines, and Gripen NG fourth-generation fighter jets, it is possible to see a growing awareness in Brazil about the importance of domestic development of major weapons systems and platforms (e.g. high-skilled jobs and technology transfer). This notion becomes even more relevant when considering the rapid advance of disruptive technologies, such as artificial intelligence, hypersonic, space technologies, quantum technologies, big data and cybernetics (NATO, 2020).

However, the prolonged period of the Brazilian political, economic, and social crisis, accompanied by the country's international downturn, casts doubt on which objectives military transformation will serve. Given the complexity of the challenges to contemporary military power, it is increasingly hard to operate with full effectiveness in all military scenarios and spectrums of operations. While the Latin American landscape is becoming more implicated in great power competition, Brazil's defence sector is broadening (e.g. Operations Green Brazil against environmental crimes in the Amazon) and this is reducing its capacity to face conventional threats and challenges.

Even though the current Brazilian defence management model can guarantee a high level of autonomy and bargaining space between the three military branches, international experiences demonstrate that this model cannot produce military change (Teixeira Júnior, 2019). The dilemma, for example, between 'Presence Strategy' (especially in the Amazon region) and Conventional Deterrence (particularly in South Atlantic) highlights the existing doubts about how the current doctrinal and strategic pillars of the Brazilian Armed Forces can meet contemporary defence challenges.

The uncertainties of the global geopolitical landscape and the rapid technological advances demand quick answers from national security and defence organisations. It also produces clear repercussions for defence industry and defence budgets. 


\section{The (dis)connection between defence budget and force structure in Brazil}

In general, national defence budgets have three essential categories: (i) personnel (e.g. regular forces, reservists and military, as well civilian pensions payments); (ii) research, development and procurement of defence equipment; and (iii) training, exercises, operations and maintenance. NATO member countries, for example, have adopted two primary goals. The first is to spend $2 \%$ of GDP on national defence to indicate a country's political will to contribute to NATO's defence efforts. The second goal is to allocate at least $20 \%$ of defence expenditure on equipment (e.g. aircraft, tanks, frigates, submarines and communication systems). Generally, NATO's $20 \%$ guideline is perceived as a crucial indicator for the scale and pace of modernisation. The main reason is that 'where expenditures fail to meet the $20 \%$ guideline, there is an increasing risk of equipment becoming obsolete, growing capability and interoperability gaps among Allies, and a weakening of Europe's defence industrial and technological base' (NATO, 2021a). As a result, NATO member states have been spending, on average, $50 \%$ of their defence budget on personnel (NATO, 2021b) ${ }^{11}$.

As displayed in Table 2, not all NATO members succeed in meeting these two goals simultaneously. Nevertheless, expenditure on equipment has become a top priority in many countries around the globe. China, for example, according to official data, spent $33.2 \%$ of its military budget on equipment and $34.9 \%$ on personnel in 2010. That same figure in 2017 rose to $41.1 \%$ and $30.8 \%$, respectively (China, 2019, p. 39).

NATO's Top 6 defence expenditures (NATO, 2021 - June 2021) (US Dolars - Constant 2015 prices and exchange rates - year 2019)

\begin{tabular}{|c|c|c|c|c|c|c|c|}
\hline & Country & Const. 2015 & $\begin{array}{c}\text { Target 1: } \\
\% \text { GDP }\end{array}$ & $\begin{array}{c}\text { Target 2: } \\
\text { EQUIPMENT }\end{array}$ & PERSONNEL & OTHER (O\&M) & INFRAST. \\
\hline 1 & USA & 701.563 & $3.5 \%$ & $27.5 \%$ & $38.9 \%$ & $32.3 \%$ & $1.3 \%$ \\
\hline 2 & UK & 65.368 & $2.1 \%$ & $22.9 \%$ & $34.1 \%$ & $41.0 \%$ & $2.1 \%$ \\
\hline 3 & GERMANY & 48.807 & $1.4 \%$ & $14.7 \%$ & $45.3 \%$ & $36.1 \%$ & $4.0 \%$ \\
\hline 4 & FRANCE & 47.712 & $1.8 \%$ & $24.5 \%$ & $45.8 \%$ & $26.6 \%$ & $3.1 \%$ \\
\hline 5 & ITALY & 22.499 & $1.2 \%$ & $17.0 \%$ & $70.2 \%$ & $12.1 \%$ & $0.7 \%$ \\
\hline 6 & CANADA & 21.905 & $1.3 \%$ & $13.8 \%$ & $49.5 \%$ & $33.9 \%$ & $2.7 \%$ \\
\hline
\end{tabular}

Equipment: expenditure includes major equipment expenditure and R\&D devoted to major equipment.

Personnel: expenditure includes military and civilian expenditure and pensions.

Other expenditure: includes operations and maintenance expenditure, other R\&D expenditure and expenditure not allocated among above-mentioned categories.

Infrastructure: expenditure includes NATO common infrastructure and national military construction.

Table 2. NATO's Top 6 defence expenditures (NATO, 2021 - June 2021). Source: based on Defence Expenditure of NATO Countries (2014-2021). June 11 (PR/CP (2021)094, NATO Public Dimension Division, Press Release.

Available at: https://www.nato.int/nato static fl2014/assets/pdf/2021/6/pdf/210611-pr-2021-094-en.pdf

${ }^{11}$ Portugal (64,7\%), Italy (60,5\%) and Slovenia (60,3\%), for example, are the countries that spent the most on personnel in 2021 (estimates) (Nato, 2021b, p. 13). 
Silva, Peterson Ferreira; Teixeira Júnior, Augusto W. M. The relationship between defence policy, the defence Budget and force structure in contemporary Brazil.

(Accessed: 15 August 2021).

In South America, according to the SIPRI military database (see Graph 1), several countries spent more on defence in 2020 as a percentage of GDP than in Brazil (1.4\%). These include Bolivia (1.6\%), Chile (1.9\%), Uruguay (2.3\%), Ecuador (2.4\%) and Colombia (3.4\%).

\section{Military expenditure by country in South America as percentage of Gross Domestic Product - GDP, 2010-2020 (SIPRI 2021)}

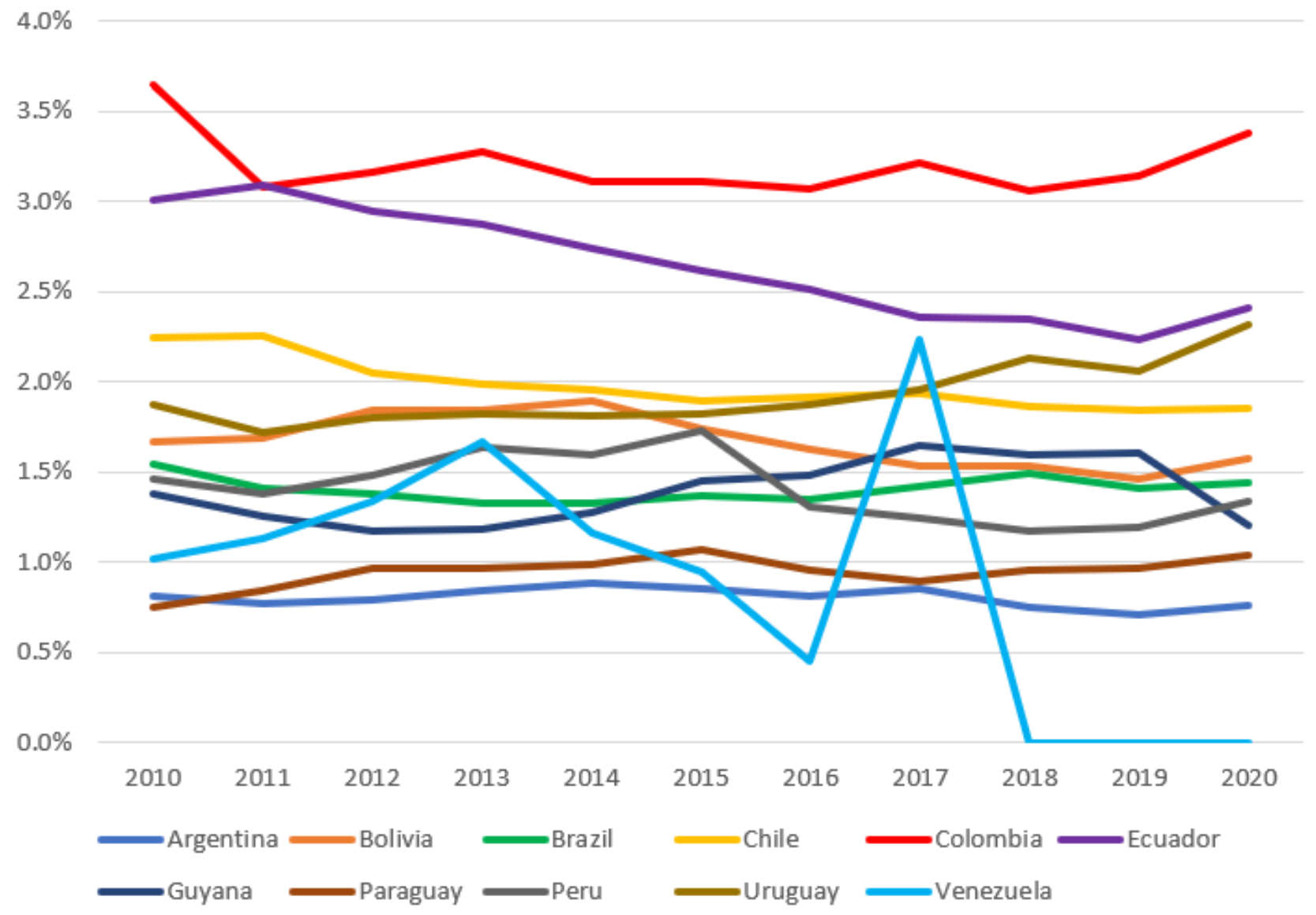

Graph 1. Military expenditure by country in South America as a percentage of Gross Domestic Product - GDP (2010-2020). Source: SIPRI Military Expenditure Database - Military expenditure by country as a percentage of gross domestic product, 1949-2020. Data were unavailable for Venezuela between 2018-2020. Available at: https://www.sipri.org/databases/milex (Accessed: 15 August 2021).

Nonetheless, both the size of the Brazilian economy and military spending are considerably higher compared, for example, to Colombia, Ecuador or Uruguay. In 2019 Brazil ranked ninth among the world's largest GDPs (US\$1,839,758 million), and there is no other South American country among

S RASILIANA: Journal for Brazilian Studies. Vol. 10, No. 2, 2021. ISSN 2245-4373. 
the 15 largest GDPs in the globe. Colombia, by contrast, ranked 39th (US\$ 323,616 million) (World Bank, 2021). Regarding military spending, Brazil ranked 15th among the world's higher military expenditures in 2020 (US\$ 19.7 billion or $1.4 \%$ of GDP). In the same year, Colombia ranked 26th (US\$ 9.2 billion or $3.4 \%$ of GDP) (Silva, Tian, and Marksteiner, 2021). In addition, Brazilian total military expenditure has been significant and stable, especially over the last two decades. As shown in Graph 2, since 1988, Brazil has had a stable level of military spending at around 1.5\% of GDP. This represents one of the highest percentages of military spending across South American countries.

\section{Brazil - Military expenditure by country as percentage of gross domestic product, 1988-2020 (SIPRI, 2021)}

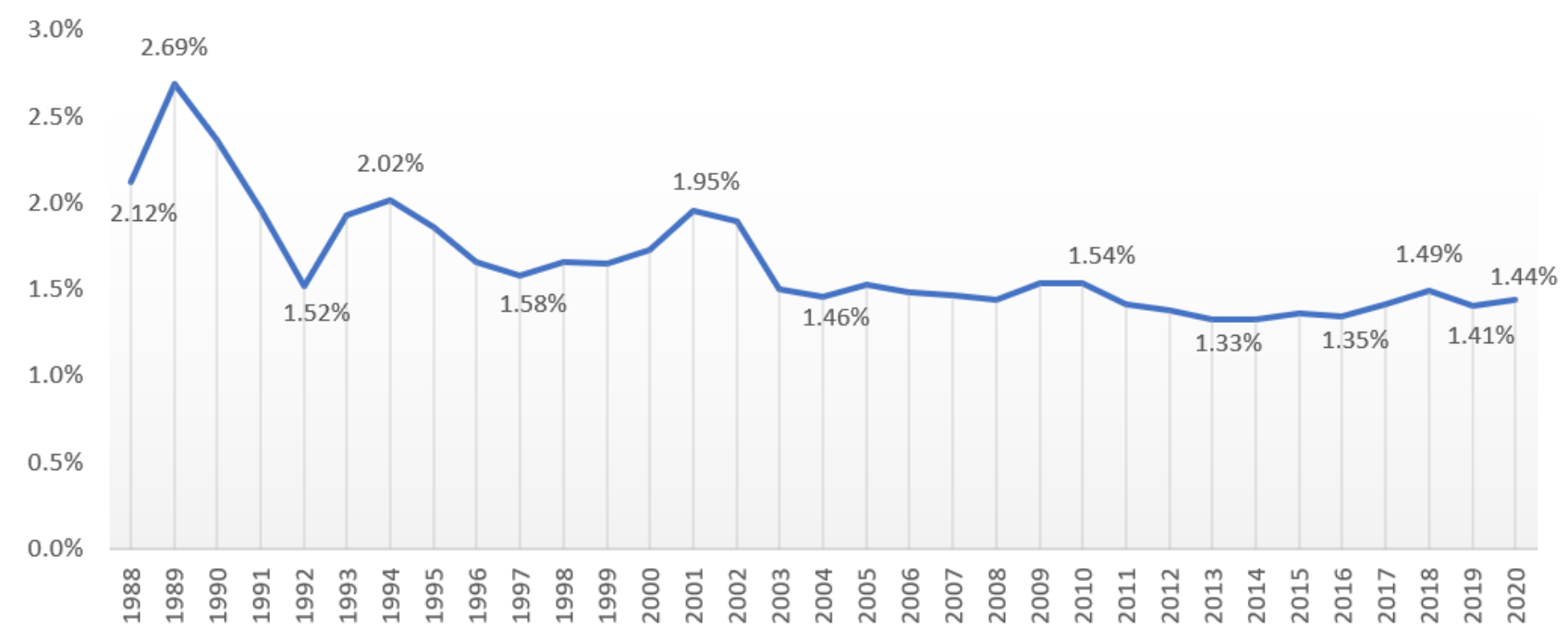

Graph 2. Brazil - Military expenditure by country as a percentage of Gross Domestic Product, 1988-2020. Source: SIPRI Military Expenditure Database - Military expenditure by country as a percentage of gross domestic product, 1949-2020. Available at: https://www.sipri.org/databases/milex (Accessed: 15 August 2021).

Relatively high costs on personnel and low investments traditionally characterised Brazil's military spending. In 2019, according to MoD data (Figure 2), Brazil spent approximately R $\$ 111$ billion on defence $(1,53 \%$ of GDP). Nearly $79.7 \%$ of that amount was allocated to personnel (R $\$ 88.6$ billion), $5.5 \%$ on Operations and Maintenance $(\mathrm{O} \& \mathrm{M})(\mathrm{R} \$ 6.1$ billion) and only $13.1 \%$ on Investments (R $\$ 14.6$ billion). ${ }^{12}$

\footnotetext{
${ }^{12}$ Brazilian Central Bank - https://www.bcb.gov.br/conversao, data of quotation: 09/09/2020. The calculation made is for information purposes only and does not replace the provisions of the Brazilian exchange regulations for specific conversion cases.
} 
Silva, Peterson Ferreira; Teixeira Júnior, Augusto W. M. The relationship between defence policy, the defence Budget and force structure in contemporary Brazil.

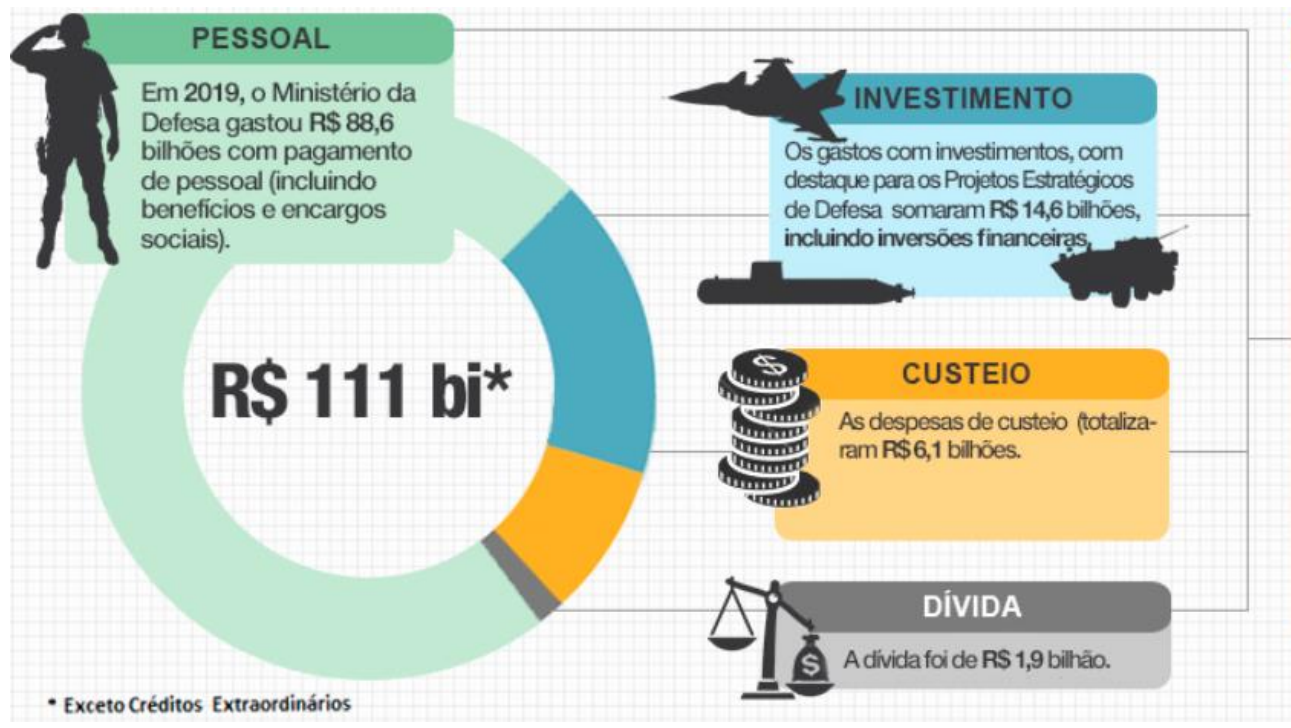

O orçamento do Ministério da Defesa, em 2019, chegou a RS 111 bilhões.

Cerca de $79,7 \%$ dos recursos destinou-se ao pagamento de pessoal. Pelas funcões que exerce, é inerente à Defesa Nacional ter grande quantitativo de pessoal.

Aproximadamente 5,5\% destinou-se ao custeio, e outros cerca de $13,1 \%$ apoiaram os investimentos.

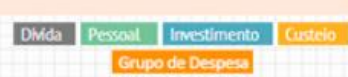

Figure 2. Ministério da Defesa - Grupos de Despesa (2019). Source: Ministério da Defesa [online]. Published on 09/09/2020. Available at: https://www.gov.br/defesa/pt-br/assuntos/orcamento-e-financas-1/orcamento-efinancas-1 (Accessed: 15 August 2021).

The most relevant Brazilian military acquisition projects (see Figure 3) demand about $\mathrm{R} \$ 83$ billion alone until 2041 (approximately US $\$ 15$ billion) ${ }^{13}$. In this context, the current Brazilian military budgetary profile (high expenses for personnel and low investments) will be an enormous challenge for Brazilian national defence policy over the next few years.

The amount needed to guarantee the ongoing contracts of its main military acquisition projects alone totalled $\mathrm{R} \$ 8.7$ billion in 2021. However, the military received approximately half (49\%) that amount (R\$ 8.4 billion) (see Figure 4$)$.

\footnotetext{
${ }^{13}$ Brazilian Central Bank - https://www.bcb.gov.br/conversao, data of quotation: 05/05/2021. The calculation made is for information purposes only and does not replace the provisions of the Brazilian exchange regulations for specific conversion cases.
} 


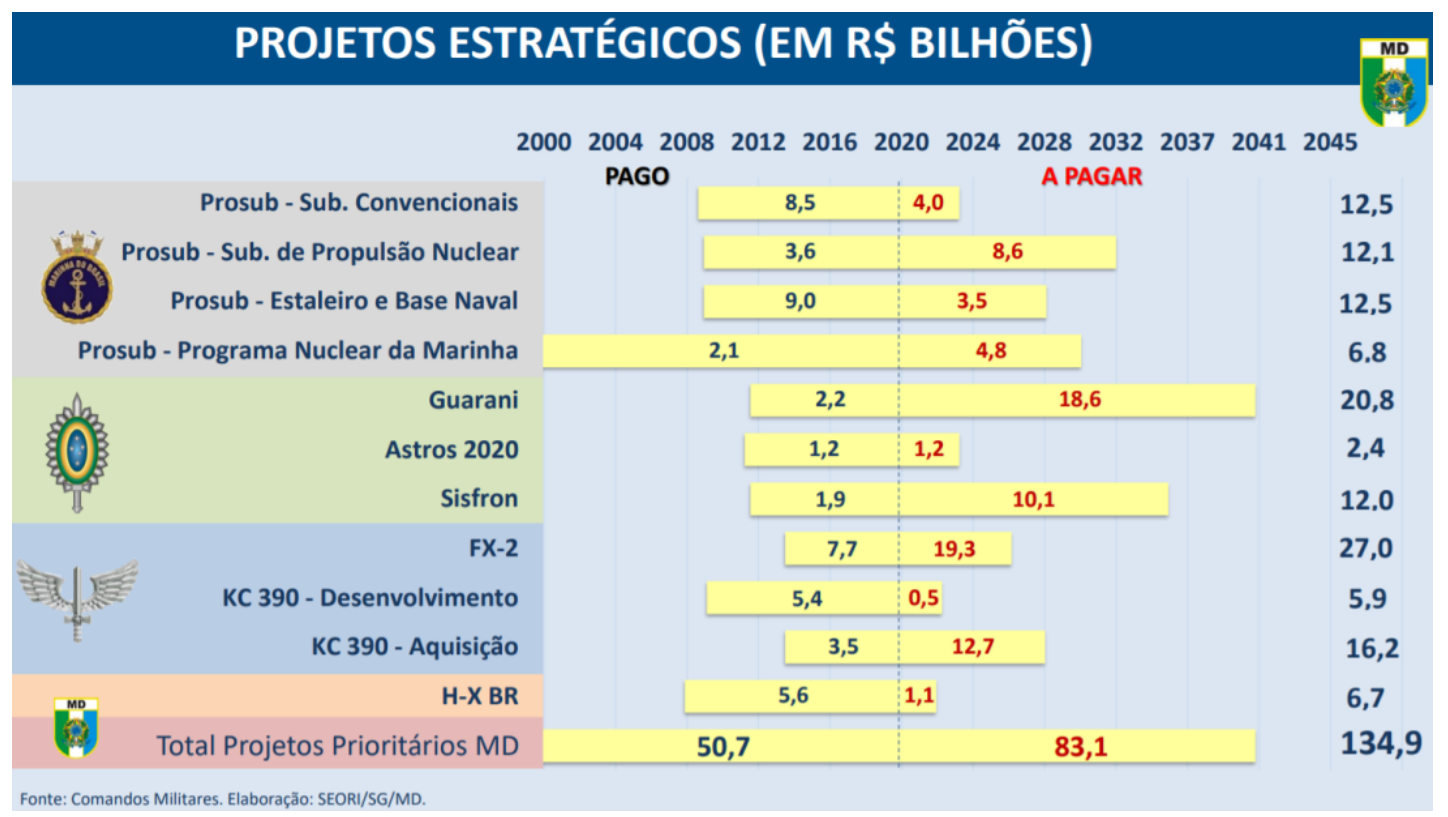

Figure 3. Projetos Estratégicos (em R $\$$ bilhões). Source: Braga Netto, Walter Souza. Apresentação pública do Ministro da Defesa na Comissão de Relações Exteriores e Defesa Nacional (CREDN). Câmara dos Deputados, 5 de maio de 2021, slide 14.

Available at: https://www2.camara.leg.br/atividade-legislativa/comissoes/comissoespermanentes/credn/apresentacoes-em-eventos/apresentacoes-de-convidados-em-eventos-de-2021-oculta/0505-audiencia-publica-md-e-comandantes/md (Accessed: 15 August 2021).

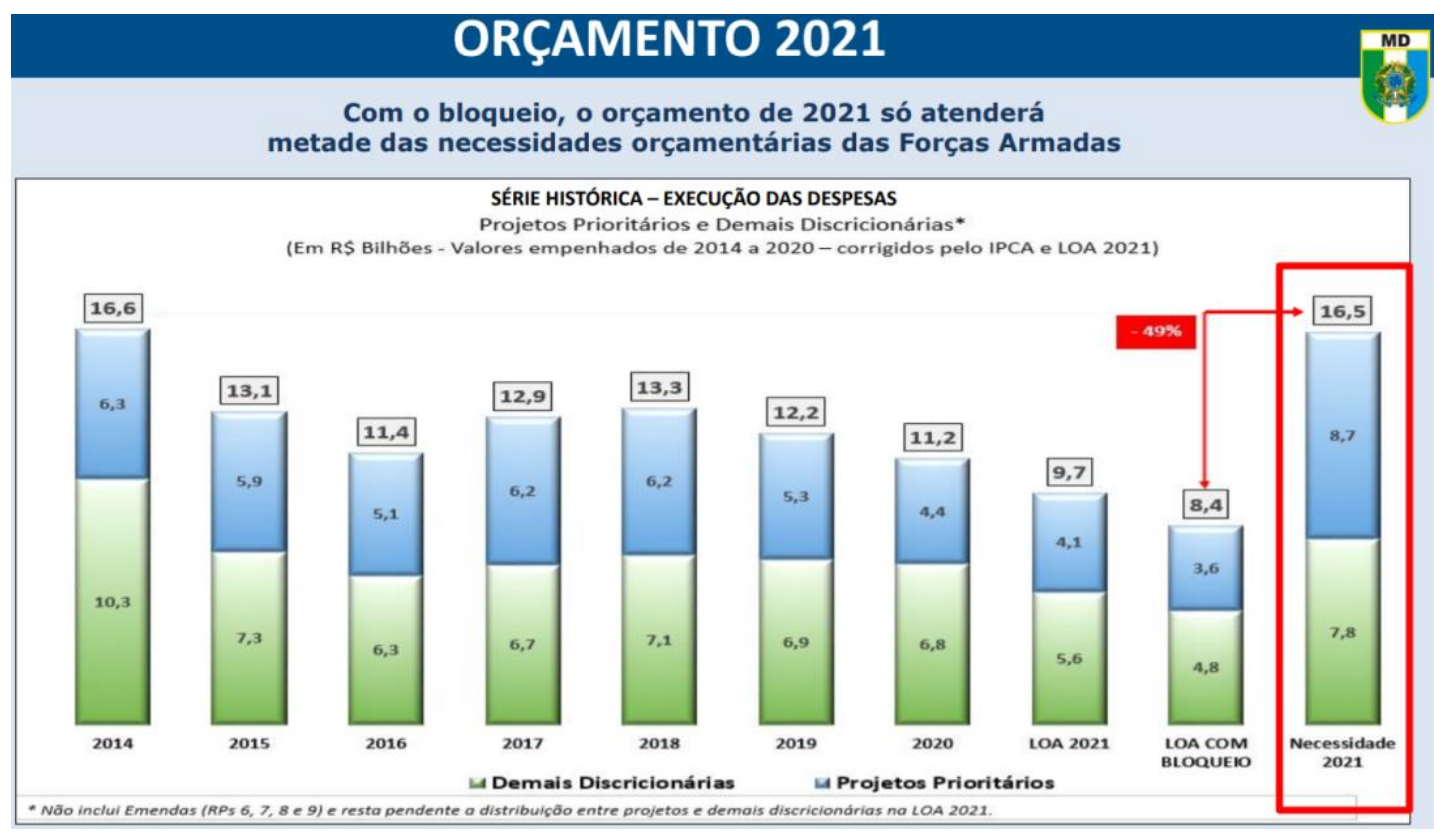

Figure 4. Ministério da Defesa - Orçamento 2021. Source: Braga Netto, Walter Souza. Apresentação pública do Ministro da Defesa na Comissão de Relações Exteriores e Defesa Nacional (CREDN). Câmara dos Deputados, 5 de maio de 2021, slide 13 . 
Available at: https://www2.camara.leg.br/atividade-legislativa/comissoes/comissoes-

permanentes/credn/apresentacoes-em-eventos/apresentacoes-de-convidados-em-eventos-de-2021-oculta/0505-audiencia-publica-md-e-comandantes/md (Accessed: 15 August 2021).

In practice, this delicate situation means that each year there are fewer resources available to maintain the approximately 366,500 active military personnel at adequate levels of readiness (Army: 214,000, Navy: 85,000 and Air Force: 67,500). The effectiveness of the reserve forces (estimated at more than 1.3 million members) is also open to doubt (IISS, 2021, p. 397). Moreover, although promised in the 2008 and 2012 Strategies, no Joint Permanent Regional Commands were created (Brazil, 2008). Alternatively, this data could be interpreted as reflecting the trends towards a prevalent option for missions other than external security, traditionally labour-intensive and in line with the country's strategic culture (e.g. support national development and the 'Presence Strategy' in the national territory).

The Brazilian defence budget tends to be around 1.5\% of GDP. This means that there will be scant budgetary room for higher defence spending given other equally relevant priorities for Brazilian society, such as health, education, sustainable development, public security, and infrastructure. Given this background, the MoD foresees a reduction of $10 \%$ of Armed Forces personnel in 10 years. However, this measure alone will be inadequate to solve the problem of the mismatch between personnel and investments expenditures (Schreiber, 2019).

In addition, the EMCFA has been implementing Capability-Based Planning (CBP) in the Armed Forces (Brazil, 2019), which is also a challenge due to the need to strengthen the 'joint culture' between the services (Taliaferro et al., 2019, p. 17-18). According to Law 97/1999 (the same one that created the MoD), the Navy, the Army and the Air Force manage individually the budgetary resources allocated to them in the budget of the MoD (Brazil, 1999b) ${ }^{14}$.

A possible first step to tackle these challenges would be to do in Brazil what the GoldwaterNichols Act (1986) did in the United States, such as to (i) strengthen the role of the Chairman of the Joint Chiefs of Staff (CEMCFA), 'in order for him to be able to provide vital, objective, independent military advice' to the Brazilian Defence Minister and the President; (ii) create the position of Vice Chairman of the Joint Chiefs of Staff; and (iii) reinforce the concept of jointness, especially concerning the careers of senior officers, by requiring them to gain professional experience outside of their service to advance further in their careers (Carter, 2016; Lother, 2004).

\section{Conclusions}

The objective of this paper was to analyse the main challenges in the relationship between Brazilian defence policy, defence budget and the Armed Force's current structure. We undertook an analytical approach connecting defence policy to budget execution. Also, our analyses shed light on the effects

\footnotetext{
${ }^{14}$ Brazil (1999b), Art. 12, § $3^{\circ}$.
} 
of civilian neglect in defence policy and its consequences in force structure in a challenging geopolitical landscape.

Instead of following the international trend to elaborate an integrated national security policy, we observe that successive Brazilian governments have insisted on elaborating and implementing uncoordinated policies for the areas of intelligence, national defence and public security. This process produced several policy documents with a lack of coordination between them, such as the National Intelligence Policy (PNI - 2016), PND, END and LBDN (2012, 2016 and 2020), and National Policy for Public Security and Social Defence (PNSPDS - 2018).

Even though Brazil's defence management model can guarantee a high level of autonomy and bargaining space between the three military branches, international experiences demonstrate that this branch-centric model cannot produce desired military change. This argument is relevant when considering the fast pace of disruptive technologies, such as AI, hypersonic, space technologies, quantum technologies, big data and cybernetics.

This paper also demonstrates that Brazil now represents one of the world's largest economies, and has one of the highest military expenditures in the world. Furthermore, it has also maintained a relatively stable level of military spending of around $1.5 \%$ of GDP over the last two decades. However, there are fewer resources each year to maintain the approximately 366,500 active military personnel at adequate levels of readiness. This is due to high levels of spending on Personnel (2019: 79.7\%), with comparatively low spending on Investments (2019: 13.1\%) and Operations and Maintenance (2019: 5.5\%).

The most promising remedy for this situation seems to be the successful implementation of the Capability-Based Planning (CBP) methodology in the Brazilian MoD. However, even this alternative also represents a significant challenge. According to Law 97/1999, the Navy, Army and Air Force manage individually the budgetary resources allocated to them in the MoD.

Possible policy alternatives include: (i) seeking a better balance between the Armed Forces personnel and investments spending, (ii) ensuring full implementation of Capability-Based Planning, (iii) strengthening the role of the Chairman of the Joint Chiefs of Staff (Chefe do Estado-Maior Conjunto das Forças Armadas - CEMCFA, in Portuguese) ${ }^{15}$, (iv) creating the position of Vice Chairman of the Joint Chiefs of Staff; and (v) requiring that senior officers gain professional experience outside of their military branches to advance further in their careers. However, without a more active civilian direction of the military and a more assertive defence policy (e.g. clear priorities and civilian defence careers), the traditional bureaucratic insulation (or autonomy) shall prevail over the needed reforms towards modern and democratic security and defence sectors in Brazil.

\footnotetext{
${ }^{15}$ In Brazil, CEMCFA is not necessarily the highest ranked commissioned officer of the Armed Forces (Chief of Defence $-\mathrm{CHOD})$.
} 
Silva, Peterson Ferreira; Teixeira Júnior, Augusto W. M. The relationship between defence policy, the defence Budget and force structure in contemporary Brazil.

\section{References}

Alisson, Elton. (2021) 'Droughts may increase in South America by the end of the century, study suggests'. Agência FAPESP. July 21.

Almazroui, M., Ashfaq, M., Islam, M.N. et al. (2021) ‘Assessment of CMIP6 Performance and Projected Temperature and Precipitation Changes Over South America'. Earth Systems Environment 5, 155-183.

Antunes, P. (2002) SNI e ABIN: uma leitura da atuação dos serviços secretos brasileiros no século XX. Rio de Janeiro: Fundação Getúlio Vargas.

Brazil. (1983) Lei no 7.170, de 14 de dezembro.

Brazil. (1988) Constituição da República Federativa do Brasil.

Brazil. (1999a) Lei no 9.883, de 7 de dezembro.

Brazil. (1999b). Lei complementar $n^{-}$97, de 9 de junho.

Brazil. (2007) Lei no 11.530, de 24 de outubro.

Brazil. (2008) Decreto $n^{0}$ 6.703, de 18 de dezembro.

Brazil. (2010) Lei complementar n⿳ํㅜㄹ, de 25 de agosto.

Brazil. (2013a) Decreto Legislativo no 373. Available at: https://www2.camara.leg.br/legin/fed/decleg/2013/decretolegislativo-373-25-setembro-2013-777085publicacaooriginal-141221-pl.html (Accessed: 15 August 2021).

Brazil. (2013b) Resolução no 2, de 2013-CN. Available at: https:/www2.camara.leg.br/legin/fed/rescon/2013/resolucao-2-22-novembro-2013-7774449publicacaooriginal-141944-pl.html (Accessed: 15 August 2021).

Brazil. (2016a) Decreto no 8.793, de 29 de junho.

Brazil. (2016b) Lei no 13.260, de 16 de março.

Brazil. (2018a) Decreto Legislativo no 179. Available at: https://www2.camara.leg.br/legin/fed/decleg/2018/decretolegislativo-179-14-dezembro-2018-787452publicacaooriginal-156961-pl.html (Accessed: 15 August 2021).

Brazil. (2018b) Lei n⿳⺈ 13.675, de 11 de junho.

Brazil. (2018c) Decreto $n^{0}$ 9.288, de 16 de fevereiro.

Brazil. (2019) ‘20 anos de MD: EMCFA é fundamental na coordenação do emprego conjunto das Forças Armadas'. Ministério da Defesa, Assessoria de Comunicação Social (ASCOM), MD Notícias. Brasília-DF, 02 de julho. Available at: https://www.gov.br/defesa/pt-br/centrais-de-conteudo/noticias/ultimasnoticias/20-anos-de-md-emcfa-e-fundamental-na-coordenacao-do-emprego-das-forcas-armadas-emoperacoes-e-exercicios-militares-conjuntos-e-na-atuacao-em-operacoes-de-paz (Accessed: 15 August 2021).

Brazil. (2021). 'Revogação da Lei de Segurança Nacional segue para a sanção presidencial. Senado Federal'. Agência Senado, Augusto 10. Available at:

https://www12.senado.leg.br/noticias/materias/2021/08/10/revogacao-da-lei-de-seguranca-nacionalsegue-para-a-sancao-presidencial (Accessed: 15 August 2021).

Bresser Pereira, Luiz Carlos. (1998) 'A reforma do estado dos anos 90: lógica e mecanismos de controle'. Lua

B RASILIANA: Journal for Brazilian Studies. Vol. 10, No. 2, 2021. ISSN 224.5-4373. 
Silva, Peterson Ferreira; Teixeira Júnior, Augusto W. M. The relationship between defence policy, the defence Budget and force structure in contemporary Brazil.

Nova, São Paulo, n. 45, p. 49-95.

Bruneau, T. C. (2018) Democratic Politics in Brazil Advances in Accountability Mechanisms and Regression in CivilMilitary Relations. Pittsburg: Panoramas.

Brustolin, Vitelio Marcos. (2014) 'Dimensões e aplicações do Orçamento de Defesa do Brazil' / 'Dimensions and executions of the Defense Budget of Brazil'. Mural Internacional, [S.1.], v. 5, n. 1, p. 38-45, jun. 2014. ISSN 2177-7314.

Buzan, Barry; Hansen, Lene. (2009) The Evolution of International Security Studies. Cambridge: Cambridge University Press.

Cairo, Heriberto. (2008) 'A América Latina nos modelos geopolíticos modernos: da marginalização à preocupação com sua autonomia'. Cad. CRH [online], vol.21, n.53, pp.219-235.

Carter, Ash (2016). 'Remarks on Goldwater-Nichols at 30: An Agenda for Updating'. Center for Strategic and International Studies. April 5 - As Delivered by Secretary of Defense Ash Carter. CSIS Building, Washington, D.C. Available at: https://www.defense.gov/Newsroom/Speeches/Speech/Article/713736/remarks-on-goldwater-nichols-at30-an-agenda-for-updating-center-for-strategic/ (Accessed: 15 August 2021).

Cepik, M. (2003) Espionagem e democracia: agilidade e transparência como dilemas na institucionalização de serviços de inteligência. Rio de Janeiro: Fundação Getúlio Vargas.

Cepik; Marco; Bertol, Frederico Licks (2016) `Defense policy in Brazil: bridging the gap between ends and means?'. Defence Studies, 16:3, 229-247.

Cervo, Amado Luiz; Lessa, Antônio Carlos. (2014) ‘O declínio: inserção internacional do Brasil (2011-2014)’. Rev. bras. polít. int., Brasília, v. 57, n. 2, p. 133-151, December.

Chile. (2017) Libro de la Defensa Nacional de Chile 2017.

Chile. (2020) Política de Defensa Nacional de Chile 2020.

China. (2019) China's National Defense in the New Era - The State Council Information Office of the People's Republic of China. July [online].

Available at: http://www.chinadaily.com.cn/specials/whitepaperonnationaldefenseinnewera.pdf (Accessed: 15 August 2021).

DCAF - Geneva Centre for Security Sector Governance. (2012) SSR in a nutshell - Manual for introductory training on Security Sector Reform. Geneva: DCAF.

DCAF - Geneva Centre for the Democratic Control of Armed Forces. (2015) 'National Security Policies'. SSR Backgrounder Series. Geneva: DCAF.

Dorman, Andrew M.; Kaufman, Joyce P. (2014) Providing for National Security - a comparative analysis. 1st edition. Stanford: Stanford Security Studies.

Ellis, Evan. (2018) 'The Future of Latin America and the Caribbean in the Context of the Rise of China'. Center for Strategic and International Studies, CSIS Americas Program. November 21.

Fiori, José Luís. (2013) ‘O Brasil e seu ‘Entorno Estratégico' na primeira década do século XXI' in Sader, Emir (ed.). 10 anos de governos pós-neoliberais no Brasil: Lula e Dilma. São Paulo: Boitempo; Rio de Janeiro: FLACSO Brasil.

Fuccille, Luis Alexandre. (2006) Democracia e questão militar: a criação do Ministerio da Defesa no Brasil. Tese 
Silva, Peterson Ferreira; Teixeira Júnior, Augusto W. M. The relationship between defence policy, the defence Budget and force structure in contemporary Brazil.

(doutorado) - Universidade Estadual de Campinas, Instituto de Filosofia e Ciencias Humanas, Campinas, SP.

Gurganus, Julia. (2018) ‘Russia: Playing a Geopolitical Game in Latin America’. Carnegie Endowment for Peace. May 3.

Herbst, John; Marczak, Jason. (2019) ‘Russia's intervention in Venezuela: What's at stake?' Atlantic Council, Sept. 12.

IISS - The International Institute for Strategic Studies. (2021) The Military Balance: The Annual Assessment of Global Military Capabilities and Defence Economics. IISS.

Kaplan, Robert D. (2019) 'A New Cold War Has Begun'. Foreign Policy. January 7.

Lima, R. C., and O. Medeiros Filho. (2019) ‘O Papel do Exército Brasileiro no Setor de Segurança: Implicações para a Defesa e o Emprego das Forças Armadas' in Andrade, I. de O., V. L. Lange, O. Medeiros Filho, R. C. Lima (eds.) Desafios Contemporâneos para o Exército Brasileiro, 95-132. Brasília: Ipea.

Lima, Raphael C. (2019) 'Strategic Communications as a tool for great power politics in Venezuela'. Defence Strategic Communications, vol.6, Spring 2019.

Lima, Raphael C.; Medeiros Filho, Oscar. (2018) ‘Segurança, defesa e o emprego da Força no Brasil: trajetórias e desafios politicos'. Anais do $10^{0}$ Encontro Nacional da Associação Brasileira de Estudos de Defesa (Enabed), Setembro 3-5.

Lima, Raphael C.; Silva, Peterson F.; Rudzit, Gunther. (2020a) ‘No power vacuum: national security neglect and the defence sector in Brazil'. Defence Studies, 21:1, 84-106.

Lima, Raphael C.; Silva, Peterson F.; Rudzit, Gunther. (2020b) `National security neglect and the defence sector in Brazil'. King's College London (KCL) - Brazil Institute Blog, December 11. Available at: https://blogs.kcl.ac.uk/brazil/page/2/ (Accessed: 15 August 2021).

Lother, James R. III. (2004) Victory on the Potomac - The Goldwater-Nichols Act Unifies the Pentagon (Volume 79). Williams-Ford Texas A\&M University Military History Series. Texas A\&M Univ. Press.

Louth, John; Taylor, Trevor. (2019) British Defence in the 21st century. 1st edition. Routledge.

Mattos, Carlos de Meira. (2002) Geopolítica e Modernidade: a geopolítica brasileira. Rio de Janeiro: Biblioteca do Exército Editora.

NATO - North Atlantic Treaty Organization. (2020) ‘Science \& Technology Trends 2020-2040'. NATO Science $\mathcal{E}$ Technology Organization, March.

NATO - North Atlantic Treaty Organization. (2021a) Funding NATO. 07 May. Available at: https://www.nato.int/cps/en/natohq/topics 67655.htm\#: :text=NATO\%20common\%2Dfunded\%20budget s\%20and,its\%20commands\%20and\%20military\%20infrastructure. (Accessed: 15 August 2021).

NATO - North Atlantic Treaty Organization. (2021b) Defence Expenditure of NATO Countries (2014-2021). June 11 (PR/CP (2021)094 NATO Public Dimension Division, Press Release. Available at: https://www.nato.int/nato static fl2014/assets/pdf/2021/6/pdf/210611-pr-2021-094-en.pdf (Accessed: 15 August 2021).

New Zealand. (2016) National Security System Handbook. Department of the Prime Minister and Cabinet, August. Available at: https://dpmc.govt.nz/sites/default/files/202010/National\%20Security\%20System\%20Handbook\%202016.pdf (Accessed: 15 August 2021).

Nugent, Ciara; Campell, Charlie. (2021) 'The U.S. and China Are Battling for Influence in Latin America, and 
Silva, Peterson Ferreira; Teixeira Júnior, Augusto W. M. The relationship between defence policy, the defence Budget and force structure in contemporary Brazil.

the Pandemic Has Raised the Stakes'. Time, Feb. 4.

Oliveira, Eliézer Rizzo. (2009) 'A Estratégia Nacional de Defesa e a reorganização e transformação das Forças Armadas'. Interesse Nacional. Abril. [online]. Available at: http://interessenacional.com.br/2009/04/01/aestrategia-nacional-de-defesa-e-a-reorganizacao-e-transformacao-das-forcas-armadas/ (Accessed: 15 August 2021).

Pérez-Peña, Richard; Stevis-Gridneff. (2019) 'Brazil's rainforest fires prompt alarm and anger in Europe'. The New York Times. August 23.

Reuters. 'Rio police draws international ire as 25 killed in drug gun battle'. Reuters.com May 7, 2021. Available at: https://www.reuters.com/world/americas/20-dead-rio-de-janeiro-shootout-paper-2021-05-06/ (Accessed: 15 August 2021).

Schreiber, Mariana. (2019) ‘O que ganham e o que perdem os militares na reforma da Previdência de Bolsonaro?'. BBC News, Brasil, Brasília-DF, 20 de março.

Silva, Diego Lopes da; Tian, Nan; Marksteiner, Alexandra. (2021) ‘Trends in world military expenditure, 2020'. SIPRI Fact Sheet, April.

Silva, P. F. (2015) A política industrial de defesa no Brasil (1999-2014): intersetorialidade e dinâmica de seus principais atores. Tese de Doutorado, Instituto de Relações Internacionais, Universidade de São Paulo, São Paulo.

Silva, P. F. (2019a) 'A guerra do futuro já começou e o Brasil enfrenta o desafio do abismo tecnológico'. Centro de Estudos Estratégicos do Exército (CEEEx). Análise Estratégica, v.11 (1), Dez/Fev. Available at: http://www.ebrevistas.eb.mil.br/CEEExAE/article/view/2116/1710 (Accessed: 15 August 2021).

Silva, P. F. (2019b) ‘Base Industrial de Segurança e Defesa nacionais no Brasil: a janela de oportunidade da segurança integrada' in Israel de Oliveira Andrade, Valério Luiz Lange, Oscar Medeiros Filho e Raphael Camargo Lima (eds.). Desafios contemporâneos para o Exército Brasileiro [online]. Brasília.

Soares, S. A. (2006) Controles E Autonomia: As Forças Armadas e o Sistema Político Brasileiro (1974-1999). São Paulo: Ed. UNESP.

Taliaferro, Aaron C.; Gonzalez, Lina M.; Tillman, Mark; Ghosh, Pritha; Clarke, Paul; Hinkle, Wade. (2019). Defense Governance and Management: Improving the Defense Management Capabilities of Foreign Defense Institutions - A Guide to Capability-Based Planning (CBP). Institute for Defense Analyses (IDA), February. Available at: https://www.ida.org/-/media/feature/publications/d/de/defense-governance-andmanagement--improving-the-defense-management-capabilities/d-10369.ashx (Accessed: 15 August 2021).

Teixeira Júnior, Augusto W. M. (2018) ‘A Reconfiguração do Tabuleiro Internacional e suas Implicações Geoestratégicas para o Brasil'. Centro de Estudos Estratégicos do Exército: Artigos Estratégicos, v. 5, Brasília, p. 7-30.

Teixeira Júnior, Augusto W. M. (2019) ‘Para pensar a transformação do Exército'. EBLOG - Blog do Exército Brasileiro. Available at: http://eblog.eb.mil.br/index.php/menu-easyblog/para-pensar-a-transformacao-doexercito.html (Accessed: 15 August 2021).

Teixeira Júnior, Augusto W. M. (2020) ‘O Entorno Estratégico Brasileiro na Geopolítica das Grandes Potências: a Crise da Venezuela e seus Impactos para o Brasil'. Artigos Estratégicos, v. 8, p. 7-25.

UN - United Nations. (2016) Human Security Handbook. United Nations. Human Security Unit [online] January. Available at: https://www.un.org/humansecurity/wp-content/uploads/2017/10/h2.pdf (Accessed: 15 August 2021). 
Silva, Peterson Ferreira; Teixeira Júnior, Augusto W. M. The relationship between defence policy, the defence Budget and force structure in contemporary Brazil.

United Kingdom. (2021) Integrated Review of Security, Defence, Development and Foreign Policy. HM Government. March.

World Bank. (2021) ‘Gross domestic product 2019'. World Development Indicators Database, 12 February. Available at: https://databank.worldbank.org/data/download/GDP.pdf (Accessed: 15 August 2021).

Zenker, Ana Luiza. 'Mangabeira Unger espera críticas ao Plano Nacional de Defesa'. Agência Brasil - Empresa Brasil de Comunicações (EBC). Sept. 7. Available at: http://memoria.ebc.com.br/agenciabrasil/noticia/200809-07/mangabeira-unger-espera-criticas-ao-plano-nacional-de-defesa (Accessed: 15 August 2021). 